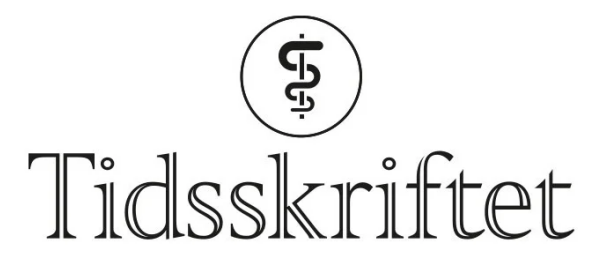

DEN NORSKE LEGEFORENING

\title{
Nytt rapporteringssystem for katastrofemedisinsk innsats
}

\author{
KOMMENTAR OG DEBATT
}

\section{MARIUS REHN}

Marius Rehn (f. 1974) er førsteamanuensis ved Universitetet i Stavanger, lege i spesialisering ved Anestesiavdelingen, Akershus universitetssykehus, og seniorforsker ved Stiftelsen Norsk Luftambulanse.

Forfatter har fylt ut ICMJE-skjemaet og oppgir ingen interessekonflikter.

Email: marius.rehn@norskluftambulanse.no

\section{Verdens første nettside for rapportering av akuttmedisinske innsats ved større ulykker er nylig lansert.}

Katastrofemedisinen er utviklet til et eget medisinskvitenskapelig felt hvor behovet for strukturerte data er stort. I en fersk systematisk litteraturstudie avdekket vi at det eksisterer ti maler for rapportering av den medisinske prehospitale håndteringen av større ulykker (1).

Siden disse malene er lite anvendt, arrangerte Stiftelsen Norsk Luftambulanse og Londons Air Ambulance en konsensusprosess blant europeiske katastrofemedisinske eksperter. Dette resulterte i en rapporteringsmal, som nylig ble publisert i Scandinavian Journal of Trauma, Resuscitation and Emergency Medicine (2) samt på nettstedet majorincidentreporting.org. Anvendbarheten av rapporteringssystemet vil bli studert som grunnlag for fremtidige oppdateringer.

Alt innsatspersonell som er direkte involvert i håndtering av større ulykker oppfordres til å rapportere sine erfaringer gjennom malen. Rapportene vil være fritt tilgjengelige, og det vil ikke være noen avgift for å bruke databasen, verken for forfattere eller lesere.

Målet er at helsearbeidere systematisk kan forbedre sin akuttmedisinske beredskap for fremtidige hendelser ved å analysere tidligere hendelser.

\section{LITTERATUR}

1. Fattah S, Rehn M, Reierth E et al. Systematic literature review of templates for reporting prehospital major incident medical management. BMJ Open 2013; 3: eo02658. [PubMed] [CrossRef]

2. Fattah S, Rehn M, Lockey D et al. A consensus based template for reporting of pre-hospital major incident medical management. Scand J Trauma Resusc Emerg Med 2014; 22: 5. [PubMed] [CrossRef] 
Publisert: 13. mai 2014. Tidsskr Nor Legeforen. DOI: 10.4045/tidsskr.14.0431

Mottatt 26.3. 2014, første revisjon innsendt 8.4. 2014, godkjent 10.4. 2014. Redaktør: Kari Tveito.

(C) Tidsskrift for Den norske legeforening 2023. Lastet ned fra tidsskriftet.no 26. april 2023. 